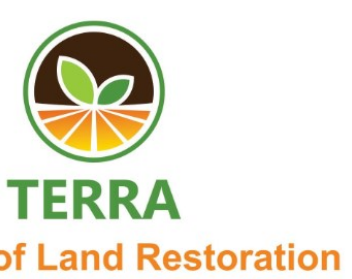

\title{
Growth and Yield of Soybean with Application of Liquid Organic Fertilizer and Arbuscular Mycorrhizal Fungi in Ultisols
}

\author{
Lisa Septiani ${ }^{1}$, Yudhy Harini Bertham ${ }^{2 *}$, Hesti Pujiwati ${ }^{1}$, Bilman Wilman Simanihuruk ${ }^{1}$ \\ ${ }^{1}$ Agroecotechnology Department, University of Bengkulu, Bengkulu, 38121, Indonesia \\ ${ }^{2}$ Soil Science Department University of Bengkulu, Bengkulu, 38121, Indonesia \\ email :yudhyhb@unib.ac.id
}

\begin{abstract}
Soybean (Glycine max (L.) Merill) is the third most important food crop after rice and corn which contains protein and other nutrients essential for the body. Ultisol soil is a less fertile soil that has many limitations on its physical, chemical, and biological properties. Efforts that can be made include the use of liquid organic fertilizer (LOF) and arbuscular mycorrhizal fungi (AMF). This research was conducted from February to May 2020, in Beringin Raya, Muara Bangka Hulu District, Bengkulu City with an altitude of $+10 \mathrm{~m}$ above sea level. The purpose of this study was to explain the growth and yield of soybeans due to the application of liquid organic fertilizers and arbuscular mycorrhizal fungi in Ultisols. The research design used was a randomized complete block design (RCBD) with 2 factors with three replications. The first factor is the LOF dose which consists of four levels, namely: 0, 20, 40, and $60 \mathrm{~mL} \mathrm{~L}^{-1}$. The second factor is the AMF dose with three levels, namely; 0,5 , and $10 \mathrm{~g}_{\text {plant }}{ }^{-1}$. The results showed that there was no interaction between LOF and AMF. Giving a LOF concentration of $60 \mathrm{~mL} \mathrm{~L} \mathrm{~L}^{-1}$ gave the highest yield on the growth and yield of soybeans, as well as the optimum concentration for seed/plant weight, which was $28.114 \mathrm{~mL} \mathrm{~L}^{-1}$, and the number of seeds was $37.589 \mathrm{~mL} \mathrm{~L}^{-1}$. AMF dosage of $10 \mathrm{~g}$ plant $^{-1}$ gave the best growth and yield of soybean plants.
\end{abstract}

Keywords : soybean, Ultisol, liquid organic fertilizer, arbuscular mycorrhizal fungi

\section{INTRODUCTION}

Soybean (Glycine max (L.) Merill) is the third most important food crop after rice and corn (Wahyudin, 2017). Soybeans contain protein and other nutrients that are very important for the body and are raw materials for the industry for making tempeh, tofu, soy sauce, soy milk and various other preparations that are very popular with the community for nutritional improvement and the price is also relatively cheap (Rohman \& Saputro, 2016; Mapegau, 2006). Thus, soybeans will always be sought after by the public and the need will always increase.

Indonesian soybean production fluctuated from 2014 to 2018 , namely 955,000 tons, 963,000 tons, 860,000 tons, 539,000 tons, and 983,000 (Kementrian Pertanian, 2018). Indonesian soybean production has not been able to meet the needs, as evidenced by the existence of soybean imports from year to year. Soybean imports from 2014 to 2018 amounted to 1.965.811 tons, 2.256.932 tons, 2.261.803 tons, 2.671.914 tons and 2.585.809 tons (Badan Pusat Statistik, 2018).
One of the efforts that can be made to increase soybean crop production is land intensification and extensification. Intensification is an improvement in the cultivation system that can be carried out using organic fertilizers and biological fertilizers, while the extensification is carried out which is to utilize land that has low fertility such as Ultisol soil.

Ultisols are a soil order that is less fertile and has many limitations on physical, chemical, and biological characteristics. Based on its distribution, Ultisols have the potential to be developed as cultivation land with an area of about $25 \%$ of the total land area of Indonesia (Prasetyo \& Suriadikarta, 2006). One of the efforts to increase the productivity of ultisol soil can be done by providing organic fertilizers that can improve soil properties (Karo et al., 2017).

Organic fertilizers are classified into two types, namely solid organic fertilizers and liquid organic fertilizers. In its application, solid organic fertilizers take longer to provide nutrients to plants because they have to be changed by soil microorganisms. An alternative that can be used is the use of liquid organic 
fertilizers because they contain nutrients in the form of a solution so that they are absorbed more easily and quickly by plants (Pasdori, 2014).

Liquid organic fertilizer (LOF) is a type of organic fertilizer that contains organic matter and essential macro and micronutrients (Taufika, 2011). Thus the use of LOF will be needed to improve soil properties. The results of the research by Tamba et al. (2017), showed that giving a POC dose of $40 \mathrm{~mL} \mathrm{~L}^{-1}$ could increase the number of productive branches and the number of filled pods in soybeans. The application of organic fertilizers containing N, P, K can also increase and improve growth in the vegetative phase of plants (Sari et al., 2013).

Arbuscular mycorrhizal fungi (AMF) is a symbiotic microorganism and fungus that has mutually beneficial properties between the host plant and the fungus (Kuswandi \& Sugiyato, 2015). Thus, the use of AMF can make high-yielding plants on land with low fertility such as ultisols. AMF can play a role in plant growth, namely, it can increase $\mathrm{P}$ elements and other elements in the soil, improve soil aggregation, protect plants from infection with root pathogens, increase drought resistance, increase soil microbes, and be used for remediating contaminated soil.

AMF has hyphae that can accelerate the movement of phosphorus into plant roots, and are able to expand the nutrient uptake area in the soil (Hasanudin \& Murcitro, 2004). Thus an increase in the availability of $\mathrm{P}$ in the soil will be followed by an increase in AMF provision. According to Malik et al. (2017), administering absurcular mycorrhizal fungi (AMF) can increase soybean production on ultisol soils. According to the research results of Oktaviani et al. (2014), the provision of AMF biological fertilizer at a dose of $20 \mathrm{~g} \mathrm{plant}^{-1}$ and a consortium of microbes at a dose of $10 \mathrm{~g} \mathrm{~kg}^{-1}$ of seed were able to increase soybean yield and production. While the research results of Suherman et al., (2012) showed that giving AMF at a dose of $8 \mathrm{~g} \mathrm{plant}^{-1}$ could increase growth in plant height, leaf number, and leaf area index and gave the best results on seed plant ${ }^{-1}$ weight and 1000 soybean seed weight.

\section{MATERIALS AND METHODS}

This research was conducted from February to May 2020 in the Beringin Raya experimental garden, Muara Bangka Hulu District, Bengkulu City with an altitude of +10 masl.

Randomized Complete Block Design (RCBD) with 2 factors was used in this study. The first factor is the concentration of liquid organic fertilizer (LOF) which consists of 4 levels, namely: $\mathrm{P}_{0}: 0 \mathrm{~mL} \mathrm{~L} \mathrm{~L}^{-1}, \mathrm{P}_{1}: 20 \mathrm{~mL}$ $\mathrm{L}^{-1}, \mathrm{P}_{2}: 40 \mathrm{~mL} \mathrm{~L}^{-1}$, and $\mathrm{P}_{3}: 60 \mathrm{~mL} \mathrm{~L}^{-1}$. The second factor was the dose of arbuscular mycorrhizal fungi (AMF) consisting of 3 levels, namely: $\mathrm{M}_{0}: 0 \mathrm{~g}_{\text {plant }}{ }^{-1}$, $\mathrm{M}_{1}: 5 \mathrm{~g}_{\text {plant }}{ }^{-1}$, and $\mathrm{M}_{2}: 10 \mathrm{~g} \mathrm{plant}^{-1}$. From these two factors, 12 treatment combinations were repeated 3 times so that there were 36 experimental units.

The stages carried out in this study were soil analysis, LOF analysis, land preparation, planting, fertilization, AMF application, LOF fertilizer application, sample determination, maintenance, and harvest. The variables observed were plant height $(\mathrm{cm})$, number of leaves (strands), number of branches (branches), flowering age (wap), crown dry weight (g), root dry weight (g), number of pods (pods), number of empty pods. (pods), number of seeds (seeds), weight of seeds plant ${ }^{-1}(\mathrm{~g})$, weight of 100 seeds $(\mathrm{g})$, weight of seeds/plot (g), and P content of tissue (\%).

Observation data were statistically analyzed using analysis of variance (ANOVA) at 5\% level and Orthogonal Polynomial to determine the relationship between independent variables and dependent variables.

\section{RESULTS AND DISCUSSION}

The results of the analysis of variance showed that there was no interaction between giving LOF and the addition of AMF on the growth and yield of soybean plants. The concentration of LOF had a significant effect on the number of pods, and weight of seeds plot ${ }^{-1}$, plant height, number of seeds, the weight of seeds plant ${ }^{-1}$, and tissue P content. The administration of AMF dose significantly affected the number of seeds, and weight of seeds/plot, plant height, and tissue P content (Table 1).

Table 1. Analysis of variance growth and yields of soybean due to LOF and AMF in Ultisol

\begin{tabular}{|c|c|c|c|}
\hline \multirow{2}{*}{ Variable } & \multicolumn{3}{|c|}{ The source of diversity } \\
\hline & LOF & AMF & Interaction \\
\hline Plant height & $\begin{array}{c}13.55 \\
*\end{array}$ & $\begin{array}{c}30.24 \\
*\end{array}$ & $2.51 \mathrm{~ns}$ \\
\hline Number of leaves & $0.42 \mathrm{~ns}$ & $0.12 \mathrm{~ns}$ & $0.40 \mathrm{~ns}$ \\
\hline Number of branches & $0.58 \mathrm{~ns}$ & $1.73 \mathrm{~ns}$ & $0.72 \mathrm{~ns}$ \\
\hline Flowering age & $0.93 \mathrm{~ns}$ & $1.32 \mathrm{~ns}$ & $0.93 \mathrm{~ns}$ \\
\hline Crown dry weight & $0.53 \mathrm{~ns}$ & $0.22 \mathrm{~ns}$ & $0.43 \mathrm{~ns}$ \\
\hline Root dry weight & $0.58 \mathrm{~ns}$ & $0.24 \mathrm{~ns}$ & $0.50 \mathrm{~ns}$ \\
\hline Number of pods & $3.16^{*}$ & $1.15 \mathrm{~ns}$ & $1.41 \mathrm{~ns}$ \\
\hline Number of empty pods & $0.67 \mathrm{~ns}$ & $0.74 \mathrm{~ns}$ & $0.41 \mathrm{~ns}$ \\
\hline Number of seeds & $6.98 *$ & $5.71 \mathrm{~ns}$ & $2.33 \mathrm{~ns}$ \\
\hline Weight seeds plant ${ }^{-1}$ & $7.85 *$ & $0.83 \mathrm{~ns}$ & $1.66 \mathrm{~ns}$ \\
\hline Weight of 100 seeds & $0.29 \mathrm{~ns}$ & $1.27 \mathrm{~ns}$ & $1.92 \mathrm{~ns}$ \\
\hline Weight seeds plot ${ }^{-1}$ & $3.23 *$ & $3.62 *$ & $0.54 \mathrm{~ns}$ \\
\hline Tissue P content & $\begin{array}{c}10.11 \\
*\end{array}$ & $7.63^{*}$ & $1.23 \mathrm{~ns}$ \\
\hline
\end{tabular}

* significant at $5 \%$ level $(\mathrm{P} \leq 0,050)$; ns non significant $(\mathrm{P}>0,050)$

The relationship between LOF concentration and soybean plant height forms a positive linear curve pattern, 
with the coefficient of determination $\left(\mathrm{R}^{2}\right)$ of 0.7331 or can be explained as $73.31 \%$. Each addition of $1 \mathrm{~mL} \mathrm{~L}^{-1}$ LOF will increase the height of soybean plants by an average of $0.1095 \mathrm{~cm}$ (Figure 1).

This is by the statement of Sampurno et al. (2016) which states that giving LOF with a concentration of $60 \mathrm{~mL} \mathrm{~L}^{-1}$ tends to increase plant height compared to other treatments. Research results by Saputra et al. (2020) showed that increasing the concentration of LOF to $100 \mathrm{~mL} \mathrm{~L}^{-1}$ tends to increase the fresh weight and dry weight of cat whiskers.

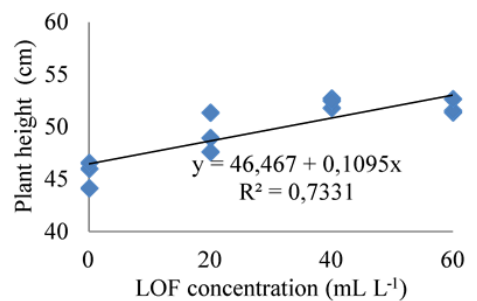

Figure 1. Relationship between LOF concentration and plant height.

The addition of LOF concentrations is useful for meeting the macro and micronutrient needs of plants. Giving LOF can help metabolism in plants due to the water content in the LOF for nutrient solubility, so that nutrient transport from the roots to all parts of the plant will run well (Herawati et al., 2017). According to Sari et al. (2014), the provision of liquid organic fertilizers of $20 \mathrm{cc}$ and $40 \mathrm{cc}$ was able to increase the height of soybean plants when compared to those without LOF.

The provision of LOF concentration and number of pods of soybean crops form a positive linear pattern which means that each level of LOF concentration is up to $60 \mathrm{~mL} \mathrm{~L}^{-1}$ followed by an increase in the number of pods (Figure 2).

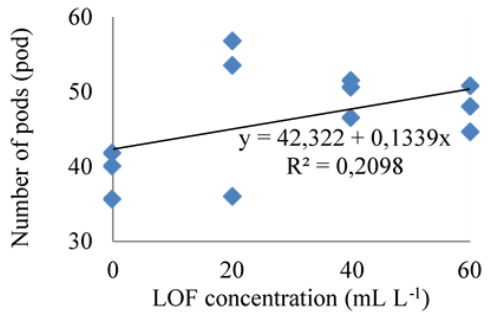

Figure 2. Relationship between LOF concentration and number of pods

The coefficient of determination $\left(\mathrm{R}^{2}\right)$ is 0.2098 or can be explained by $20.98 \%$. This means the addition of LOF concentration of $1 \mathrm{~mL} \mathrm{~L}^{-1}$ can increase the number of soybean pods by 0.1339 pods. The increase in the number of pods plants ${ }^{-1}$ is thought to be due to the content of N, P, K in LOF. According to Hamzah (2014), LOF administration gives real different results on a variable number of pods soybean plants, compared to without LOF administration. Meanwhile, according to
Walid \& Susylowati (2016), NASA's organic fertilizer showed a very noticeable difference to the total number of pods plants ${ }^{-1}$.

The relationship between LOF concentration and soybean seed count forms a quadratic pattern with a coefficient of determination $\left(\mathrm{R}^{2}\right)$ of 0.6624 or $66.24 \%$ (Figure 3).

The optimum concentration of LOF on the

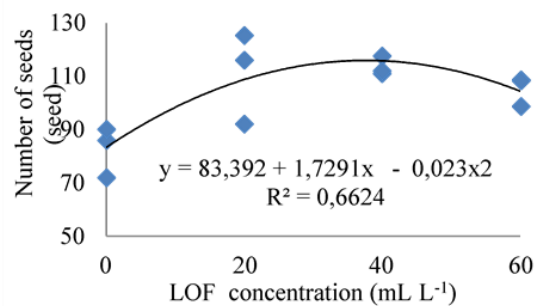

Figure 3. Relationship between LOF concentration and number of seeds

increase in the number of soybean seeds is $37,589 \mathrm{~mL} \mathrm{~L}^{-1}$ with an average seed count of 115.89 seeds. Each addition of $1 \mathrm{~mL} \mathrm{~L}^{-1}$ LOF will increase the number of soybean seeds by an average of 1.7291 seeds, while the addition of LOF concentration above the optimum concentration will decrease the number of soybean seeds by 0.023 seeds. When the enlargement of pods and the filling of soybean seeds requires a lot of elements $\mathrm{K}$. Element $\mathrm{K}$ is required by plants for the formation of sugars and flour substances for the process of photosynthesis, and also helps in the formation of starch and proteins. Element $\mathrm{P}$ is also needed plants in the formation of seeds (Puspitasari \& Elfarisna, 2017). This statement is also supported by Tamba et al. (2017) which states that the content of elements $\mathrm{N}, \mathrm{P}$, and $\mathrm{K}$ in LOF can improve vegetative growth of plants through the increase in the total leaf area and the amount of chlorophyll which in this case is related to the process of photosynthesis and increased production results.

The influence of LOF concentration on seed/plant weights forms a relationship with the quadratic curve pattern, with a coefficient of determination $\left(\mathrm{R}^{2}\right)$ of 0.4696 or $49.96 \%$ (Figure 4). It shows that the addition of LOF can increase the weight of seeds/plants up to optimum concentration, which is $28,114 \mathrm{~mL} \mathrm{~L}^{-1}$ with a seed/plant weight of $18,313 \mathrm{~g}$, while the provision of LOF above the optimum concentration will decrease the weight of soybean seeds/plants by $0.0035 \mathrm{~g}$.

This is not following the results of Sinuraya et al. (2015) research which showed that the provision of LOF

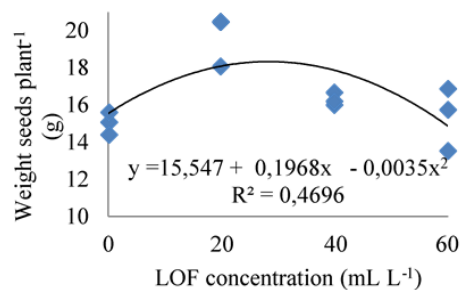

Figure 4. Relationship between LOF concentration and weight seeds plant ${ }^{-1}$ 
concentration of $40 \mathrm{~mL} \mathrm{~L}^{-1}$ gave the highest results to seed/plant weight. The addition of LOF concentration is very influential on the weight of seeds. This is suspected because the role of $\mathrm{P}$ and $\mathrm{K}$ contained in LOF can supply soybean plant nutrients until the generative phase. Element $\mathrm{P}$ can accelerate and strengthen the growth of young plants into mature plants accelerate seeding, and can also increase grain production (Puspitasari \& Elfarisna, 2017). According to Wicaksono (2015), LOF concentrations showed noticeable different results. The best result of LOF administration is produced by a concentration of $120 \mathrm{~mL} \mathrm{~L}^{-1}$. Concentration LOF 0-60 $\mathrm{mL} \mathrm{L}^{-1}$ affects weight seeds plot $^{-1}$ by forming a positive linear curve pattern. This indicates that each addition of LOF $1 \mathrm{~mL} \mathrm{~L}^{-1}$ can increase the weight of seeds/plot on average by 1,895 $\mathrm{g}$ (Figure 5).

The administration of LOF containing N, P and K can improve the vegetative growth of plants that can affect the process of photosynthesis of plants. A good process of photosynthesis will increase the carbohydrates produced as food reserves in the form of pods and will accumulate in the form of seeds (Sari et al., 2014). This is in contrast to the opinion of Walid \& Susylowati (2016) stated that the provision of LOF concentration has a real effect and tends to give the highest results on variable dry weight seeds plots ${ }^{-1}$.

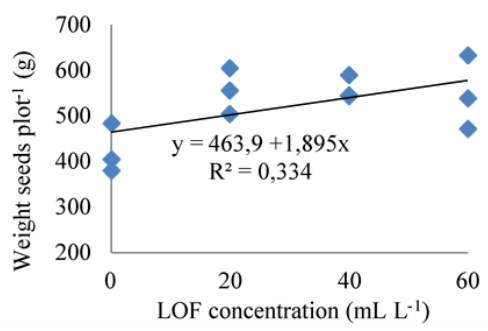

Figure 5. Relationship between LOF concentration and weight seeds plot ${ }^{-1}$

The relationship of POC concentration and $\mathrm{P}$ levels of soybean plant tissue forms a positive linear curve pattern (Figure 6). Each addition of $1 \mathrm{~mL} \mathrm{~L}^{-1} \mathrm{LOF}$ will increase the $\mathrm{P}$ level of soybean tissue by an average of $0.0015 \%$. The coefficient of determination (R2) is 0.4744 . The coefficient of determination indicates that the contribution of LOF concentration to tissue $\mathrm{P}$ levels in soybean crops can be explained by $47.44 \%$.

The increase in LOF concentration is directly proportional to the increase in tissue $\mathrm{P}$ levels in soybean crops. P nutrient content in LOF can increase the absorption of $\mathrm{P}$ on soybean leaves, this is suspected because of the high availability of $\mathrm{P}$ to increase the absorption of $\mathrm{P}$ in plant tissues. According to Bachtiar et al. (2018), the solubility of soil $\mathrm{P}$ will increase with the addition of organic materials such as LOF. Increasing microbial activity in the soil will also spur the production of various beneficial elements in the soil for plants, especially elements P. Solihin et al. (2018) states that element P in the soil and its absorption in plants is influenced by soil conditions, climate, and the ability of plants to absorb nutrients from the soil. High absorption of $\mathrm{P}$ in the

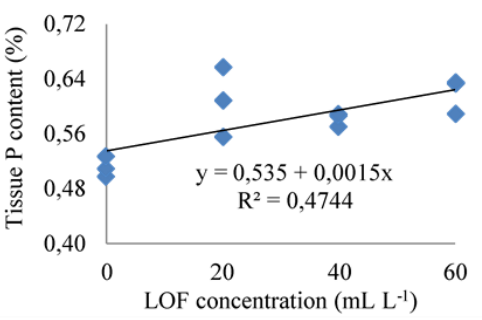

Figure 6. Relationship between LOF concentration and tissue $\mathrm{P}$ content

treatment caused by the contribution of soil P directly absorbed through the stomata due to spraying LOF.

The concentration of LOF exerts an unreal influence on variable number of leaves, number of branches, flowering age, dry weight of headers, and dry weight of roots. Nutrient content of $\mathrm{N}, \mathrm{P}$, and $\mathrm{K}$ is influential for plant growth. This is thought not only caused by the low nutrient content of LOF, but the nutrient content in the soil ultisol is also classified as very low to moderate so that the nutrient is not enough for plant growth. Good plant growth can be achieved if the nutrients needed for plant growth and development are in the form of available, balanced and in optimum concentrations and supported by environmental factors that are good for plant growth and development (Walid \& Susylowati, 2016). In addition, genetic and environmental factors also greatly influence the growth of plants such as in the flowering age. The flowering process of plants is influenced by genetic factors as well as environmental factors. Plants that can respond well to sunlight, then the flowering process is faster.

The relationship between AMF and high soy plants forms a positive linear curve pattern. This means, each addition of $1 \mathrm{~g} \mathrm{plant}^{-1}$ AMF will increase the average height of soybean crops by $0.7797 \mathrm{~cm}$, with a coefficient of determination $\left(\mathrm{R}^{2}\right)$ of 0.8221 or equivalent to $82.21 \%$ (Figure 7).

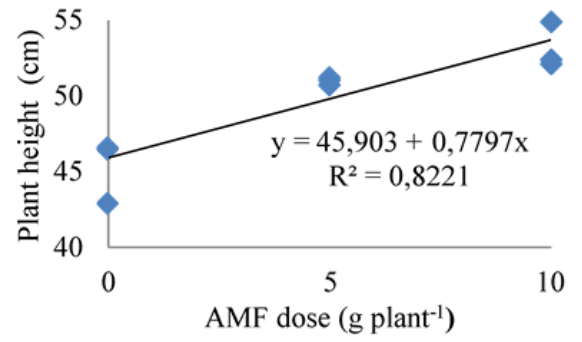

Figure 7. Relationship between AMF dose and plant height

The provision of AMF serves to help the absorption process of nutrients, especially $\mathrm{N}, \mathrm{P}$, and $\mathrm{K}$ by expanding the root system through the formation of lateral hyphae. The provision of AMF is proven to increase $\mathrm{P}$ absorption and plant growth (Fahmissidqi, 2016).

According to Oktaviani et al. (2014), the optimum dose of mycoriza (AMF) for soybean crops is $26.35 \mathrm{~g}$, while according to Charisma et al. (2012) the administration of AMF $20 \mathrm{~g} \mathrm{plant}^{-1}$ has a noticeable effect on the high variable of plants and is the optimum dose of soybean crops. 
AMF dosing with the number of soy seeds forms a positive linear curve pattern. This means, each addition of $1 \mathrm{~g} \mathrm{plant}^{-1} \mathrm{AMF}$ will increase the number of soybean seeds by an average of 2.1367 seeds (Figure 8 ). The coefficient of determination $\left(\mathrm{R}^{2}\right)$ is 0.747 . The coefficient value of determination indicates that the relationship between AMF dose and the number of soybean seeds can be explained by $74.7 \%$.

AMF application can increase soybean crop production by increasing the number of seeds. This happens because P nutrients are important in seed filling, seed seeding, and increasing grain production (Malik et al., 2017). AMF dosing has a noticeable effect with the distance of increasing the number of seeds at each given dose. This is by the opinion of Dinata (2019) which states that the administration of a dose of AMF $10 \mathrm{~g}$ plant $^{-1}$ can increase the maximum number of seeds in soybean crops. According to Malik et al. (2017), AMF administration has a real influence on the number of soybean seeds and increases crop production compared to without $\mathrm{AMF}$ administration.

AMF dosing forms a positive linear curve pattern in the weight of soybean seeds plots ${ }^{-1}$ which means that each increase in AMF dose is followed by the equation. (Figure 9).

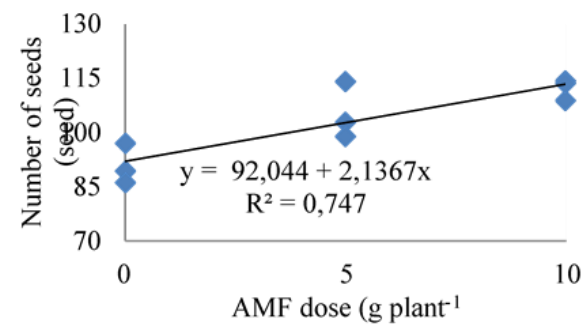

Figure 8. Relationship between AMF dose and number of seeds

This means that each addition of $1 \mathrm{~g} \mathrm{plant}^{-1}$ will increase the variable weight of soybean seeds plots ${ }^{-1}$ by an average of $11.825 \mathrm{~g}$, with a determination coefficient value $\left(R^{2}\right)$ of 0.6028 or can be explained by $60.28 \%$.

The Seed weight results are influenced by photosynthesis, element $\mathrm{N}$ plays an important role as a constituent of proteins that will be used by plants to increase the contents of pods. Element $\mathrm{P}$ plays a role in the supply and transfer of energy in all plant physiological processes such as helping to accelerate the process of pod development and eating.

Plant response due to $\mathrm{AMF}$ administration has a real effect on the number of seeds/plants, seed weight plot $^{-1}$ and weight of 100 seeds with the best dose indicated by the treatment of 5 and $10 \mathrm{~g} \mathrm{AMF} \mathrm{planting}^{-1}$ hole (Sukmasari et al., 2018). Meanwhile, according to Alfandi (2015), the administration of P fertilizer with a dose of $45 \mathrm{~kg}$ SP-36 ha ${ }^{-1}$ and CMA with a dose of $7.5 \mathrm{~g}$ planting ${ }^{-1}$ hole shows the best influence.

There is a positive linear relationship between AMF dose and $\mathrm{P}$ content in the tissue (Figure 10).
This means each addition of AMF will increase the $\mathrm{P}$ level of soybean crop tissue by an average of $0.007 \%$. The coefficient of determination $\left(\mathrm{R}^{2}\right)$ is 0.596 or can be explained by $59.6 \%$.

$\mathrm{P}$ levels of plant tissue indicate the large content of $P$ nutrients stored in plant tissues, this element is needed in

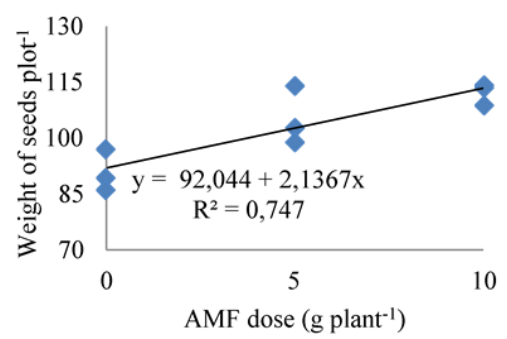

Figure 9. Relationship between AMF dose and weight of seeds plot ${ }^{-1}$

generative phases to support photosynthesis translocation of plant organs. Hara P obtained plants through the absorption of inorganic $\mathrm{P}$ by the roots (Malik et al., 2017). Based on the results of Oktaviani et al. (2014) research, plants associated with AMF can increase $\mathrm{P}$ absorption compared to those without AMF administration. This happens because AMF can provide element $\mathrm{P}$ available in the ground. According to Wardhani et al. (2019), the provision of AMF can increase the $\mathrm{P}$ element available to plants.

The results of the variant analysis showed that AMF doses had an unreal effect on variable amounts, the number of branches, flowering age, dry weight of headers, and dry root weights. AMF dose independently with the administration of $10 \mathrm{~g} \mathrm{plant}^{-1}$ gives the highest result in the variable number of leaves, dry weight of header, dry root weight, and fastest flowering age, while the highest number of branches at the dose of $5 \mathrm{~g} \mathrm{plant}^{-1}$.

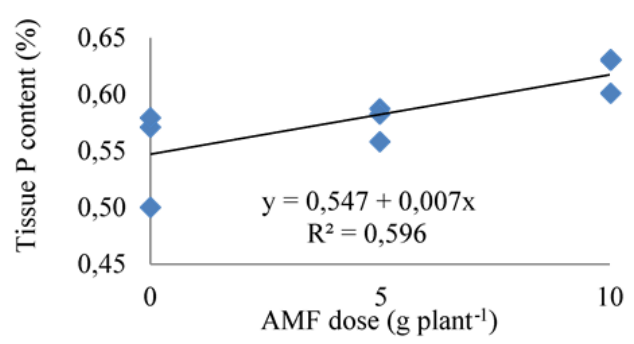

Figure 10. Relationship between AMF dose and tissue $\mathrm{P}$ content

This is alleged because environmental factors such as air temperature are needed in the vegetative and generative phases of plants. It is supported by Indriani et al. (2011), who states that AMF in plants increases at a temperature of $30{ }^{\circ} \mathrm{C}$. Factors that influence AMF infection in plant roots are light, temperature, soil fertility, and soil $\mathrm{pH}$. The best air temperature for arbuscular development is about $30{ }^{\circ} \mathrm{C}$, for colonization of mycelium on the root surface between $24-34{ }^{\circ} \mathrm{C}$, as well as sporulation and development of vesicles at a 
temperature of $35^{\circ} \mathrm{C}$. The elements in the soil that have the most effect on mycorrhiza are $\mathrm{P}$, where the high $\mathrm{P}$ content in the soil will inhibit colonization. High soil $\mathrm{N}$ content also negatively affects the growth and development of mycorrhiza. The effect of element $\mathrm{N}$ on mycorrhiza is also influenced by the availability of element $\mathrm{P}$ in the soil (Padri et al., 2015). This is supported by the opinion of Yusrinawati \& Sudantha, (2016) which states that mycorrhiza will support plant growth in nutrient deficient plant conditions such as $\mathrm{P}$ and $\mathrm{N}$, as well as colonization of roots by AMF can benefit growth in acidic soils and poor nutrients.

The AMF dose exerts an unreal influence on the variable number of pods, the number of hollow pods, and the weight of 100 soybean seeds. The content of N, $\mathrm{P}, \mathrm{K}$ on research land is classified as very low to medium which results in nutrient supply is insufficient for plant needs despite AMF inoculation. $\mathrm{N}$ nutrients play an important role as a constituent of proteins that will be used by plants to increase the amount of pod content. Also, environmental conditions suitable for the growth and development of AMF are expected to increase the high density of AMF spores. Hyphae of the AMF will infect the root part, resulting in more spores and can increase capacity in the absorption of nutrients and water. Dry conditions will stimulate the formation or development AMF sporulation process becomes lower (Padri et al., 2015).

Generally, AMF is more resistant to soil $\mathrm{pH}$ changes. Optimal AMF development ranges from 3.9 to $5.9 \mathrm{pH}$. In addition to $\mathrm{pH}$, several factors can influence the development of AMF spores namely soil temperature and air temperature. The temperature range suitable for AMF development is $30^{\circ} \mathrm{C}$ but for colonization, the best is $28{ }^{\circ} \mathrm{C}-34{ }^{\circ} \mathrm{C}$ (Padri et al., 2015). AMF inoculations have not gone well on the number of pods, the number of hollow pods, and the weight of 100 soybean seeds. The results of Pernamasari et al. (2016) research showed that the administration of AMF has no effect on the number of pods plants ${ }^{-1}$, the number of seeds plants ${ }^{-1}$, and the weight of dried seeds plants ${ }^{-1}$, but the administration of amf more and more will increase crop yields as the dose of AMF given. The body is microorganism as well as MVA can release various organic compounds with various functions. Gradually the bound ions of these organic compounds will be released so that plants can be utilized (Bertham et al., 2005).

\section{CONCLUSION}

There is no interaction between LOF concentration and the addition of AMF dose in growth variables or soybean crop yields. LOF concentration of $60 \mathrm{~mL} \mathrm{~L}^{-1}$ showed the highest results but has not yet reached the optimum dose for variable plant height, number of pods, seed weight plot $^{-1}$, and tissue $\mathrm{P}$ content. The optimum concentration for seed plant ${ }^{-1}$ weight is $28.114 \mathrm{~mL} \mathrm{~L}^{-1}$ and the number of seeds is $37.589 \mathrm{~mL} \mathrm{~L}^{-1}$. AMF dose of $10 \mathrm{~g} \mathrm{plant}^{-1}$ showed the highest yield, namum has not received optimum dose for soy plant growth and yield.

\section{References}

Alfandi. (2015). Kajian pertumbuhan dan hasil tanaman kacang hijau (Phaseolus radiates L.) akibat pemberian pupuk $\mathrm{p}$ dan inokulasi cendawan mikoriza arbuskular (CMA). Jurnal Agrijati, 28(1), 158-171.

Bactiar, T., Nurrobifahmi, Citraresmini, A., Flatina, A.N., Slamet, S. \& Tarmizi. (2018). Peningkatan produksi kedelai hitam varietas mutiara 2 melalui pemberian pupuk organik cair. Jakarta Selatan: Pusat Aplikasi Isotop dan Rasiasi, Badan Tenaga Nuklir Nasional. Prosiding Seminar Nasional Apisora 2018.

Badan Pusat Statistik (BPS). (2018). Impor Kedelai Menurut Negara Asal Utama https:// www.bps.go.id. 14 Februari 2019.

Bertham, Y.H., Kusmana, C. Setiadi, Y. Mansur, I. \& Sopandie, D. (2005). Introduksi pasangan CMA dan Rhizobia indigenous untuk peningkatan pertumbuhan dan hasil kedelai di Ultisol Bengkulu. Jurnal IlmuIlmu Pertanian Indonesia, 7(2), 94-103.

Charisma, A. M., Rahayu, Y.S. \& Isnawati. (2012). Pengaruh kombinasi kompos Trichoderma dan mikoriza vesikular arbuskular (MVA) terhadap pertumbuhan tanaman kedelai (Glycine max (L.) Merill) pada media tanam tanah kapur. Fakultas Matematika dan Ilmu Pengetahuan Alam, Universitas Negeri Surakarta, Surakarta.

Dinata, N. (2019). Respon pertumbuhan dan produksi beberapa varietas tanaman kedelai (Glycine max L.) terhadap pemberian fungi mikoriza arbuskular (FMA) pada tanah Ultisol. Skripsi. Fakultas Pertanian, Universitas Mumammadiyah SumateraUtara, Medan.

Fahmissidqi, D. (2016). Pengaruh pemberian berbagai dosis fungi mikoriza arbuskular terhadap pertumbuhan vegetatif tanaman kedelai (Glycine max L. Merr.). Jurnal Agroekotek, 8(1), 47-55.

Indriani, N. P., Mansyur, Susilowati, I. \& Islami, R.Z. (2011). Peningkatan produkrivitas tanaman pakan melalui pemberian fungi mikoriza arbuskular (FMA). Jurnal Pastura, 1(1), 27-30.

Hamzah, S. (2014). Pupuk organik cair dan pupuk kandang ayam berpengaruh kepada pertumbuhan dan produksi kedelai (Glycine max L.). Agrium, 18(3), 228-234..

Hasanudin \& Murcitro, B.G. (2004). Pemanfaatan mikrobia pelarut fosfat dan mikoriza untuk per- 
baikan fosfor tersedia, serapan fosfor tanah (ultisol) dan hasil jagung (pada ultisol). Jurnal Ilmu-Ilmu Pertanian Indonesia, 6(1), 8-13.

Herawati, N., Hipi, A., Aisah, A.R. \& Tantawizal. (2017). Keragaan pertumbuhan dan hasil beberapa varietas kedelai pada berbagai pupuk organik cair di lahan kering beriklim kering. Prosiding Seminar Hasil Penelitian Tanaman Aneka Kacang dan Umbi. Balai Pengkajian Teknologi Pertanian 2017, Lombok Barat, Nusa Tenggara Barat.

Karo, K. A., Lubis, A. \& Fauzi. (2017). Perubahan beberapa sifat kimia tanah ultisol akibat pemberian beberapa pupuk dan waktu inkubasi. Jurnal Agroekoteknologi, 5(2), 227-283.

Kementrian Pertanian. (2018). Statistik Pertanian. http:// epublikasi.setjen.pertanian.go.id. 31 Desember 2018.

Kuswandi, P. C. \& Sugiyanto, L. (2015). Apikasi mikoriza pada media tanam dua varietas tomat untuk peningkatan produktivitas tanaman sayur pada kondisi cekaman kekeringan. J. Sains Dasar, 4(1), 17-22.

Malik, M., Hidayat, K.F., Yusnaini, S. \& Rini, M.V. (2017). Pengaruh aplikasi fungi mikoriza arbuskula dan pupuk kandang dengan berbagai dosis terhadap pertumbuhan dan produksi kedelai (Glycine max [L.] Merill) pada ultisol. J. Agrotek Tropika, 5(2), 63-67.

Mapegau. (2006). Pengaruh cekaman air terhadap pertumbuhan dan hasil tanman kedelai (Glycine max L. Merr). Jurnal Ilmiah Pertanian KULTURA, 41(1), 43-49.

Oktaviani, D., Hasanah, Y. \& Barus, A. (2014). Pertumbuhan kedelai Glycine max L. Merrill) dengan apliasi fungi mikoriza arbuskular (FMA) dan konsorsium mikroba. Jurnal Online Agroekoteknologi, 2(2), 905-918.

Padri, M. H., Burhanuddin \& Herawatiningsih, R. (2015). Keberadaan fungi mikoriza arbuskula pada jabon putih di lahan gambut. Jurnal Hutan Lestari, 3(3), 401-410.

Pernamasari, I., Dewi, K., Irfan, M. \& Arminudin, A.T. (2016). Peningkatan efisiensi pupuk fosfat melalui aplikasi mikoriza pada kedelai. Jurnal Agroteknologi, 6(2), 23-30.

Posdori, A. H. Irianto, dan Mukhsin, 2014. Respon tanaman sawi terhadap pupuk organik cair limbah sayuran pada lahan kering ultisol. Jambi: Universitas Jambi. Prosiding Seminar Nasional Lahan Suboptimal 2014, Palembang 26-27 september 2014 ISBN: 979-587-529-9.

Prasetyo, B. H. N., dan Suriadikarta. 2006. Karakteristik dan Sebaran Ultisol di Daerah Pemetikarata. Tanah dan Iklim. Universitas Gajah Mada, Yogyakarta.

Puspitasari, A, dan Elfarisna. 2017. Respon pertumbuhan dan produksi kedelai varietas grobogan dengan penambahan pupuk organik cair dan pengurangan dosis pupuk anorganik. Prosiding Seminar Nasional. Fakultas Pertanian Universitas Muhammadiyah Jakarta, 31 Desember 2017, Tangerang Selatan.

Rohman, E. A. \& Saputro, T.B. (2016). Analisis pertumbuhan tanaman kedelai (Glycine max L.) varietas Grobogan pada kondisi cekaman genangan. Jurnal Sains dan Seni ITS, 5(2), 2337-3520.

Sampurno M. H., Hasanah, Y. \& Barus, A. (2016). Respon pertumbuhan dan produksi kedelai (Glycine max (L.)Merill) terhadap pemberian biochar dan pupuk organik cair. Jurnal Agroekoteknologi, 4(3), 21582166. DOI: https://10.32734/jaet.v4i3.13387.

Sari D. K., Hasanah, Y. \& Simanungkalit, T. (2014). Respon pertumbuhan dan produksi beberapa varietas kedelai (Glycine max (L.) Merill)) dengan pemberian pupuk organik cair. Jurnal Online Agroekoteknologi, 2(2), 653-661.

Sari, H. P., Suswanto \& Syukur, M. (2013). Daya hasil 12 hibrida harapan jagung manis (Zea mays L. var. Saccharata) di Kabupaten Moras, Sulawesi Selatan. Buletin Agrohorti. 1(1), 14-22.

Saputra, D., Sukarjo, E.I. \& Masdar. (2020). Efek konsentrasi dan waktu aplikasi pupuk organik cair kulit pisang terhadap pertumbuhan dan hasil tanaman kumis kucing (Orthosiphon aristatus). Jurnal Ilmu-Ilmu Pertanian Indonesia, 22(1), 31-37. DOI: https://doi.org/10.31186/ jipi.22.1.31-37.

Sinuraya M. A., Barus, A. \& Y. Hasanah, Y. 2015. Respon pertumbuhan dan produksi kedelai (Glycine $\max (\mathrm{L}$.) Merill) terhadap konsentrasi dan cara pemberian pupuk organik cair. Jurnal Agroekoteknologi, 4(1), 1721-1725. DOI: https://10.32734/ jaet.v4i1.12282.

Solihin, E., Sudirja, R., Damayanti, M. \& Kamaludin, N.N. (2018). Hubungan serapan N, P, dan K tanaman cabai terhadap residu di dalam tanah yang diberi pupuk organik dan NPK. Jurnal Agrikultura, 29(2), 105-110.

Suherman, Rahim, I. \& Akib, M.A. (2012). Aplikasi mikoriza vesikular arbuscular terhadap pertumbuhan dan produksi tanaman kedelai (Glycine max L. Merill). Jurnal Galung Tropika, 1(1), 1-6.

Sukmasari, M. D., Wijaya, A.A. \& Herdiana, I. (2018). Pertumbuhan tanaman kedelai (Glycine max L., Merill) dengan pemberian pupuk hayati konsorsium dan fungi mikoriza arbuskular. Universitas Majalengka. Prosiding Konser Karya Ilmiah Tingkat Nasional Tahun 2018, Kamis 13 September 2018, Majalengka, Jawa Barat. ISSN 2460-5506.

Tamba, H., Irmansyah, T. \& Hasanah, Y. (2017). Respon pertumuhan dan produksi kedelai (Glycine max (L.) Merill) terhadap aplikasi pupuk kandang sapi dan pupuk organik cair. Jurnal Agroekoteknologi, 
5(2), 307-314. DOI: https://10.32734/jaet.v5i2. 15423.

Taufika, R. (2011). Pengujian beberapa dosis pupuk organik cair terhadap pertumbuhan dan hasil tanaman wortel (Daucus carota L.). J. Tanaman Hortikultura, 1-10.

Wahyudin, A. (2017). Respon tanaman kedelai (Glycine max) varietas Wilis akibat pemberian berbagai dosis pupuk N, P, K, dan pupuk guano pada tanah Inceptisol Jatinangor. Jurnal Kultivas, 16(2), 333-339..

Walid, L. F. \& Susylowati. (2016). Pengaruh konsentrasi pupuk organik cair (POC) terhadap pertumbuhan dan hasil beberapa varietas tanaman kedelai (Glycine $\max (\mathrm{L}$.) Merill). Ziraa'ah, 41(1), 84-96.

Wardhani Y., Yuliana, A.I. \& Munir, M.M. (2019). Potensi mikoriza indigenous terhadap serapan unsur P (fosfor) di tanah litosol pada tanaman kedelai (Glycine $\max$ (L.) Merill) Varietas Anjasmoro. Exact Papers in Compilation (EPiC), $1(2), 83-86$.

Wicaksono, W.A. (2015). Respon pertumbuhan dan produksi tanaman kedelai (Glycine max (L.) Merill). terhadap pemberian pupuk $\mathrm{P}$ dan pupuk organik cair Azolla. Fakultas Pertanian. Universitas Muhammadiyah Jember, Jawa Timur. http:// repository.unmuhjember.ac.id/2051/1/ JURNAL.pdf.

Yusrunawati \& Sudantha, M. (2016). Pengaruh fungi mikoriza arbuskular (FMA) dalam meningkatkan ketahanan kekeringan, ketahanan penyakit, pertumbuhan dan hasil pada tanaman bawang. Progam Studi Magister Pengelolaan Sumberdaya Lahan Kering Program Pascasarjana, Universitas Mataram, Mataram. 